\title{
Digital portfolio of the teacher as a means of developing professional competencies
}

\author{
O.A. Nechaeva ${ }^{1 *}$ \\ ${ }^{1}$ Kaluga State University K.E. Tsiolkovsky, Kaluga, Russia
}

\begin{abstract}
The technology of the electronic portfolio of a teacher is presented, which ensures the continuous development of professional skills and assessment of competencies, for the implementation of effective professional activities using new methods of teaching and education in a modern and safe digital educational environment. The study is aimed at creating an adequate system of continuous professional development of teachers and assessment of competencies based on e-portfolio technology, taking into account Russian and international academic and professional standards, ready and able to implement professional activities at a highquality level in a modern and safe digital educational environment. The practical significance of the research carried out lies in the organization of continuous professional training and support of pedagogical personnel, the effective assessment of competencies based on the e-portfolio technology in a modern and safe digital educational environment.
\end{abstract}

\section{A problem statement}

Currently, one of the problems of education is the development of professional competencies of a teacher in accordance with the requirements of a modern digital educational environment and an adequate assessment of the level of formation of professional competencies, taking into account lifelong learning throughout life [1]. Within the framework of the study, the technology of the electronic portfolio (e-portfolio) organically fits into various modern educational systems, is an important component of the digital educational environment, provides an effective process of implementing and supporting the professional development of a teacher at all levels of education: bachelor's, master's, postgraduate, advanced training.

\subsection{The objective of the work}

This scientific and pedagogical development is based on the research of Russian (S.G. Grigoriev, V.V. Grinshkun, O.G. Smolyaninova and others) [2, 3, 4] and foreign researchers (Gill, Hwang, etc.) [5,6]. According to the author of the development, the electronic portfolio is viewed as a technology for professional development and assessment

\footnotetext{
* Corresponding author: prof-ped.gpa@mail.ru
} 
of the teacher's key competencies (supra-subject, pedagogical, subject, digital, value) in the context of lifelong education throughout life. When carrying out this study, we also took into account the results of developing a competency model for the modern digital economy of the Competence Center in the direction of "Personnel and Education". This center implements the program "Digital Economy of the Russian Federation", namely the current direction "Model of Competencies of the Digital Economy" [1]. The competency model for the digital economy was developed taking into account the requirements of society, the state and the labor market for the key competencies of the personality of the Digital Society and the realities of the 4th industrial revolution. The model became the basis for the formation of new federal state educational standards for higher education and educational programs of all levels and areas of training for future professionals in Russia.

\section{Results of the research}

Leading universities in the world use portfolio technology as an element of a holistic elearning system in an open educational space. In the world educational practice, the electronic portfolio acquires the greatest significance in the context of the implementation of the methodology for the comprehensive assessment of teacher competencies (oversubject, pedagogical, subject, digital, value) in a modern and safe digital educational environment.

By "digital portfolio" we mean the accumulated and replenished results of the teacher's professional achievements, artifacts of activities, important educational products in the digital environment. A digital portfolio allows you to access materials at any convenient time, as well as integrate it with other digital resources, including audio and video, and social networks. This allows you to build a special educational space to support the initiative and motivation of the teacher for further personal and professional development, as well as the opportunity to exchange best educational practices, develop skills of reflection and self-assessment.

The relevance of the study of the scientific, theoretical and methodological foundations for the use of electronic portfolio technology in the professional development and assessment of teachers' competencies is determined by the need for lifelong learning, taking into account the basic requirements of academic and professional standards and the modern open labor market [7,8].

These requirements reflect the need to change the content and mode of interaction between participants in the educational process and affect the features of the organization and implementation of assessment activities in the educational information environment of the university for the effective integration of teachers into the global educational space [9].

In assessing the competencies of teachers using electronic portfolio technology, the priority areas are: the continuity of reflection and learning in various formats, updating and demonstrating educational results and achievements online, providing feedback to improve the learning process.

The digital portfolio is used as an educational technology for the professional development of a Russian teacher, including all levels of education: bachelor's, master's, postgraduate studies, advanced training and assessment of the level of professional competencies (supra-subject, digital, value), various forms and methods of assessment (formative, diagnostic, current, intermediate (test, exam), state final certification) in a modern and safe digital educational environment, creating a flexible management system for a personalized educational process, introducing new forms of educational practices and replicating successful experience in other universities.

The performed analysis showed that the electronic portfolio can be effectively applied within the framework of standardized procedures for assessment, self-assessment, mutual 
assessment, and also provides an opportunity for obtaining an independent expert assessment of an experienced supervisor teacher and reflection on the artifacts of the future teacher's portfolio.

The advantage of using an electronic portfolio in the higher education system is the focus on formative assessment of competencies through high-quality feedback from the student and the teacher, focused not on the details of the content, but on determining the level of formation of the student's competencies, his educational goals, learning styles for the development and implementation of individual educational trajectories personal and professional development.

The digital portfolio provides an opportunity to organize the process of professional training of teachers, taking into account the individual needs of future teachers through the differentiation of training and to form the skills necessary for personal and professional growth and career development throughout life.

A digital portfolio at the bachelor's level contributes to the development of teachers' competencies, allowing them to use modern methods of social communicative interaction in an electronic educational environment based on the principles of cooperation; develop and implement educational projects; plan an individual trajectory of education throughout life; plan a professional career.

At the master's level, digital portfolio contributes to the development of the future master of pedagogy of universal and general professional competencies focused on solving various types of professional tasks (research, pedagogical, organizational and managerial, project) in the development and implementation of innovative educational projects at various levels in the context of digitalization with designing an individual trajectory of personal and professional development throughout life.

E-portfolio allows actualization, accumulation and demonstration of significant results of educational and extracurricular activities of teachers throughout the period of study at university and beyond, as well as further professional development in a modern and safe digital educational environment, focuses on sharing learning experiences, provides continuous communication between different participants of the educational process [1013].

E-portfolio in the conditions of multilevel education is used by students of different pedagogical and psychological and pedagogical profiles only as a means of individualization of professional training, but also in the continuous development of skills to analyze and evaluate the process of personal professional development, in designing and implementing individual educational routes [14].

In order to implement the use of digital portfolios, universities develop and implement regulations that establish the structure and content of students' digital portfolios during their studies, as well as determine the order of placement of students' individual achievements in the electronic information and educational environment of the educational organization, including in the personal account of the student and the electronic portfolio of the student on the main professional educational programs of higher education - bachelor, specialist and doctoral degrees. The Regulation on the organization of the educational process by means of a digital portfolio may also include a list of tasks and recommendations for the placement of the final works of future teachers. During the implementation of this approach is the organization of checking the levels of formation of professional competencies network partners from the system of teacher training colleges (methodologists), school teachers - supervisors, principals of schools and colleges.

Implementation of digital portfolio as an assessment technology in network interaction in teacher training contributed to the change in the content, methods and technologies of education, dictated by the new requirements for learning outcomes in the transition to the FSES. In network interaction in approbation of the results of scientific and practical 
development, the university-college-school provided their own educational resources to each other in order to improve the quality of teacher training. The university-college-school were interested in using the technology of electronic teacher's portfolio for joint use of status, material, personnel and information resources of the educational network in order to organize conditions for professional and personal development of the future teacher and organize an independent system of competence evaluation.

When describing the methodological aspect of using the portfolio in this study, the following functions are most significant: diagnostic, controlling, evaluating, organizational, operational, motivational, reflexive [15]. Further we will explain the meaning of each of the presented functions. It should be noted that, in fact, each of the presented e-portfolio functions is associated with different aspects of the process of evaluation and feedback.

The diagnostic function (monitoring and diagnostic) of the e-portfolio reflects the teacher's personal and professional development, the results of which make it possible to define the direction of further professional development.

The checking and correcting function of the e-portfolio helps teachers understand their learning and cognitive work, their level of professional learning, their learning needs and professional interests as well as identifying and correcting learning deficits.

The assessment function of the e-portfolio helps students organize and implement efficient assessment, provide feedback to the participants of the educational process, evaluate individual educational outcomes and personal achievements in order to plan individual educational paths and develop competencies. The organizational function of eportfolio provides the development of skills of goal-setting, planning, designing and forecasting of professional activities, personal and professional growth, the ability to selforganize activities.

Operational function of e-portfolio takes into account individual skills of implementation of activities in the conditions of its course, the ability to self-development in the implementation of activities in the digital educational environment. Motivational function of e-portfolio is aimed at forming and increasing the level of educational and professional motivation of teachers, teachers' interest in research work, extracurricular (social, cultural, creative, sports) activities; development of their ability to selfdetermination.

Reflexive function of e-portfolio develops skills of self-evaluation, evaluation of the results of individual educational activity, including the formation of personal criteria and indicators for the subsequent adjustment of professional activity; allows to identify discrepancies between the results obtained with the set goal, their causes, flexibly adapt to changing conditions.

In the aspect of the teacher's professional growth and development of his/her pedagogical skills the most significant are stimulation and support of motivation, forecasting of professional future, design of individual trajectories of personal and professional development.

In this connection, the development of scientific and methodological support and support for teachers in mastering the e-portfolio technology and further development of professional activity implementation skills and competence assessment skills using new teaching and learning methods in a modern and safe digital educational environment is becoming increasingly relevant [16-19].

E-portfolio is considered in the context of the methodology of individual educational experience acquisition by teachers and its use in designing further trajectories of personal and professional development.

The analysis of the state of development of the problem of e-portfolio use in the system of competence evaluation in the context of lifelong learning has revealed the following contradictions: 
- between the formation of new educational goals in Russian higher education and insufficient development of appropriate modern authentic digital assessment tools, reflecting the educational results of students;

- between the evaluation process, important for the educational institution and the evaluation, meaningful for the student, aimed at individual educational results;

- between the recognition of the potential of e-portfolio for personal and professional development of a teacher and insufficient elaboration of scientific-theoretical foundations of e-portfolio application in the professional training process.

Nowadays, the e-portfolio in higher education is considered as a component of the integral educational concept of the university, in the framework of which we can observe the change of the mode of interaction between the subjects of the educational process.

We observe a redistribution of importance between the ways of assessment - from the teacher's assessment of the formal knowledge of the student to self-assessment by the student, his continuous educational reflection; between the ways of interaction: from knowledge transfer to the interactive mode, dialogicality and continuous joint activity.

Among the problems that do not allow for "complex" evaluation of undergraduate and graduate students' educational results by means of e-portfolio, it is necessary to create the following conditions:

1. to form a unified educational state concept of using e-portfolio at all stages and levels of education and consistent systematic control of its implementation;

2. to develop legal and regulatory documents that would allow to present e-portfolio artifacts as an entrance exam for the admission to the pedagogical Master/PhD program;

3. use the e-portfolio in the educational process throughout the period of undergraduate, graduate and postgraduate education at the university and beyond;

4. develop a concept and organizational-pedagogical conditions to account for formal and significant non-formal educational outcomes of master students: professional, academic and personal;

5. create an open system for all participants in the educational process to use interactive tools of e-portfolio.

In our study we considered in more detail such conditions of the integrated assessment of educational outcomes as the inclusion of e-portfolio in the continuous learning process in the university and outside it, the actualization and accounting of formal and significant nonformal educational outcomes, as well as the use of interactive tools of e-portfolio by various participants in the educational process [20].

Taking into account the peculiarities of e-portfolio functioning in modern and safe digital educational environment, the structure and content of e-portfolio were developed taking into account the specifics of competence assessment at different educational levels: undergraduate, graduate, postgraduate, as well as in the system of professional development. This structure includes invariative and variable components aimed at effective assessment of competencies for continuous personal and professional development throughout life.

The educational process using the digital portfolio is carried out in accordance with the regulations on the use of e-portfolio within the framework of integrated curricula between the partner universities, providing for mutual obligations and agreements on certification activities (results of educational activities), use of facilities, class schedules, etc. In this case the digital portfolio may be used for the evaluation of students' performance. In this case, the digital portfolio is applicable not only to authentic assessment of students' educational outcomes, but also to assess the competence of teachers.

The University successfully operates and constantly updates its information and education environment, which includes the means of the Moodle educational platform, on 
the basis of which the e-learning courses in various disciplines are developed, in particular the disciplines aimed at mastering the e-portfolio technology.

In order to evaluate a teacher's competences, a level model is proposed, taking into account the continuing education and the possibility of developing competences with the help of a digital portfolio.

The level model of teacher's competences is presented below:

- Constructive Level. The teacher possesses methods, ways and techniques of professional activity to solve non-standard pedagogical tasks and is ready to find new nontraditional solutions independently.

- Productive Level. The teacher demonstrates professional competences and has the knowledge of the methods and techniques of professional activity and is able to find productive solutions to the main pedagogical tasks.

- Reproductive level. The teacher demonstrates some elements of professional competences; knows the main methods, ways and techniques of professional activity; is able to find solutions of the main pedagogical tasks in the presence of given typical conditions.

According to the curriculum for bachelor's and master's degree programs at USSiN 44.00.00 "Education and Pedagogical Sciences", the title and content of the disciplines on mastering the ePortfolio technology vary according to the training profile. The main content of these disciplines is aimed at mastering the methodology of creating, developing and using e-portfolio at all levels of education and in employment practices for self-assessment and authentic assessment of personal and professional competencies. At the same time, the content of the work programs of disciplines was updated and revised in accordance with the requirements of FSES of Higher Education 3 and FSES of Higher Education 3+, FSES of Higher Education 3+, professional standard of a teacher and taking into account the profile of training.

The digital portfolio is used for the state final certification procedure at the undergraduate, graduate and postgraduate levels. Artifacts of the digital portfolio for the period of training subsequently undergo the procedure of peer review before the State Final Assessment, as well as in the process of interim certification of students' activities. At the postgraduate level e-portfolio is used as a technology for assessing competencies in the format of interim certification of postgraduate students, which is carried out twice a year. Prior to the SIA, experts, who are university professors and employers, conduct an examination of students' e-portfolio materials to assess the level of development of their professional competences in accordance with the criteria and assessment levels.

\section{Conclusions}

The results of the study confirm that the electronic portfolio serves as a systemic component of the digital educational environment, ensuring continuous professional development of a teacher and assessing the level of competence development at all levels of education: undergraduate, graduate, postgraduate, and professional development in accordance with FSESE and the Professional Teacher Standard. We substantiate the effectiveness of using the electronic portfolio as a unique technology aimed at the formation and development of professional competencies of a teacher, taking into account its systematic application in the digital educational environment of the university.

We developed the structure and content of the teacher's electronic portfolio, aimed at evaluating professional competences for continuous personal and professional development, taking into account the results of formal, informal and non-formal education. The proposed elements of the developed and tested methodological support can be used in 
the training process of students of other profiles and directions in order to increase the efficiency of digitalization of education.

The article substantiates the model of effective formation and assessment of teachers' competences in mastering systemic disciplines in the process of professional training by means of a digital portfolio. This model can be partially or fully integrated into the educational process of any Russian higher education institution under the conditions of education informatization, development of digital industry 4.0, active implementation of rapidly updated high-tech computer tools and communication systems in the sphere of education.

\section{References}

1. A.M. Kondakov, A.A. Kostyleva, Digital identity, digital self-identification, digital profile: formulation of the problem, https://cyberleninka.ru/article/n/tsifrovayaidentichnost-tsifrovaya-samoidentifikatsiya-tsifrovoy-profil-postanovka-problemy (2019)

2. S.G. Grigor'ev, O.V. Andrushkova, Blended learning as the result of convergence under conditions of education informatization, Informatics and education, 2, 23-27 (2017)

3. V.V. Grinshkun, Informatization in the context of development of pedagogical education, https://cyberleninka.ru/article/v/informatizatsiya-v-kontekste-razvitiyapedagogicheskogo-obrazovaniya (2014)

4. O.G. Smolyaninova, E.A. Bezyzvestnykh, Implementing teachers' training technologies at a Federal University: E-portfolio, digital laboratory, https://onlinejournals.org/index.php/i-joe/article/view/9288 (2019)

5. L. Gill, B. Dalgarno, L. Carlson, How Does Pre-service Teacher Preparedness to Use ICTs for Learning and Teaching Develop Through Their Degree Program?, https://researchoutput.csu.edu.au/ws/portalfiles/portal/11169148/80670_1000003643p ostpub.pdf (2015)

6. B. Hwang, The effects of learning portfolio-based program on learning competencies perceived by pre-service special education teachers, In Special Education Research, 13(1), 26-59 (2014)

7. G. Falloon, From digital literacy to digital competence: the teacher digital competency (TDC) framework, https://link.springer.com/article/10.1007/s11423-02009767-4 (2020)

8. N. Sardone, Developing and engaging learning experience in preservice education, The Clearing House: A Journal of Educational Strategies, Issues and Ideas, 92(6), 235-245 (2019)

9. A. Shahroom, N. Hussin, Industrial Revolution 4.0 and Education, http://hrmars.com/hrmars_papers/Industrial_Revolution_4_0_and_Education.pdf (2018)

10. M.A. Pinskaia, Portfolio: opportunities and actual tasks, https://cyberleninka.ru/article/n/portfolio-vozmozhnosti-i-aktualnye-zadachi (2011)

11. O.G. Smolyaninova, Assessment of educational outcomes in life long learning: electronic portfolio, 362 (2016)

12. E.S. Polat, M.Iu. Bulharkina, M.V. Moiseeva, Theory and practice of distance learning, Study guide, 416 (2017) 
13. E.J. Instefjord, E. Munthe, Educating digitally competent teachers: A study of integration of professional digital competence in teacher education, https://www.sciencedirect.com/science/article/abs/pii/S0742051X16302888 (2017)

14. M. Prensky, Teaching Digital Natives, 203 (2010)

15. I.V. Robert, Informatization of education as a new area of pedagogical knowledge, Man and education, 1(30), 14-18 (2012)

16. K. Shvab, The 4th Industrial Revolution, 208 (2016)

17. E. Tezci, Teachers' effect on ict use in education: the Turkey sample, (2009)

18. A. Toffler, The Third Wave, 784 (1984)

19. S.L. Atanasian, Information educational environment of a pedagogical university, https://cyberleninka.ru/article/n/informatsionnaya-obrazovatelnaya-sredapedagogicheskogo-vuza (2007)

20. J. Zubizarreta, The Learning Portfolio: Reflective Practice for Improving Student Learning, 312 (2004) 